\title{
Examining the Effect of Task Complexity and Sequence on Speaking Ability of Iranian EFL Learners
}

\author{
Masoumeh Alipour Madarsara (Corresponding Author) \\ Department of English, Rasht Branch, Islamic Azad University, Rasht, Iran \\ E-mail: M.alipoor24@gmail.com \\ Ramin Rahimy \\ Department of English Language, Islamic Azad University, Tonekabon Branch, Iran \\ E-mail: Rahimy49@yahoo.com
}

Received: 20-07-2014

Accepted: 09-09-2014

Published: 01-01-2015

doi:10.7575/aiac.ijalel.v.4n.1p.247

URL: http://dx.doi.org/10.7575/aiac.ijalel.v.4n.1p.247

\begin{abstract}
The impetus of the present study was to examine the effect of task complexity and sequence on speaking according to performance data collected from 60 intermediate Iranian EFL learners on two tasks (a map task and a car task). In order to examine the effects of task sequence and complexity in enhancing EFL learners' speaking ability in three different areas including accuracy, fluency and complexity, descriptive statistics as well as independent samples T-tests were run to the results of each sections of the speaking test for both control and experimental groups in posttest. It was found that task sequence and complexity had significant effects on Iranian intermediate EFL learners' speaking ability. The findings of the study also revealed that the participants in the experimental group, who practiced task sequence and complexity, far outweighed the control group in complexity and fluency than the other area of the speaking test.
\end{abstract}

Keywords: TBLT, Task, Task Complexity, Task Sequence, EFL

\section{Introduction}

Frequent years of language teaching and research have proved that synthetic syllabi and analytic syllabi focusing on meaning alone will not work satisfactorily to the degree of enabling a learner to a native speaker's command of a target language. Examples of meaning- only or communicative- method classrooms in which fail learners fail to produce native- like accuracy in the target language can be French immersion programs in Canada( Harley, 1992; Kowal\& Swain, 1997).

Task- Based Language Teaching (TBLT, Long,1985) is considered as an approach to language teaching which attempts to produce native- like accuracy within a communicative classroom, in which task is the unit of analysis. Since TBLT contains a variety of methodological principles, the weakness of the earlier- mentioned programs can be compensated.

Shortcomings and also dissatisfactions of structural syllabus and CLT led to the emergence of task-based teaching as the best replacement for developing language skills of EFL language learners through interaction and meaningful tasks. As it has been mentioned frequently (Long 1996, Long and Crooks 1992, Skehan 1996, Willis and Willis 2001, Ellis 2003, 2005), TBLT (Task-based Language Teaching) provides the learners with a tangible and favorable context in which language learners get involved in using authentic input and it is quite obvious that language development will foster in this way.

With the emergence of communicative and task- based approaches in language teaching, syllabus designers have tried to make use of meaningful tasks so that they are similar to real life tasks. Another new trend developed recently in TBLT is referred to as task complexity which has been the focus of a lot of research recently. According to Robinson (2001), using complex tasks leads to improvement of language acquisition. However one of the major problems in taskbased syllabus design is addressed to task sequence and complexity because the way in which different tasks are sequenced can have a great impact on learners' achievement in speaking ability.

One of the shortcomings of the current syllabus designs seems to be rooted in the way different tasks are sequenced without much care in their cognitive load of difficulty and complexity. When task complexity factor is ignored in syllabus design and students are faced with more cognitively demanding tasks in the very beginning, they might just give up because of not having enough familiarity with the task faced with.

\section{Review of the Related Literature}

In this section, major studies on task sequence and complexity will be reviewed.

The issue of task sequence and complexity is of main concern of language instructors and syllabus designers. According to Ellis (2004), there are many factors that can affect the difficulty of a task. 
According to Gilabert (2004), the need for sequencing tasks from simple to difficult in a way that develops interlanguage caused task complexity appear in task- based language teaching. The term "task difficulty" has been defined by different scholars. According to Ellis (2003), task complexity is the extent to which a particular task is inherently easy or difficult. Robinson (2001) defines it as "the result of intentional, memory, reasoning, and other information processing demands imposed by language learner." Skehan (1998) makes use of interconnectedness for referring to task complexity which means more elements or characters make the task more difficult.

Two main models of task complexity have been developed by Robinson and Skehan\& Foster. Robinson (2001) formulated Triadic Componential Framework based on cognition hypothesis which distinguishes three task components: task complexity, task conditions and task difficulty. This framework claims that pedagogic tasks should be designed and sequenced on the basis of increases in their cognitive complexity from simple to more difficult ones so that they resemble real life tasks.

Skehan and Foster (Skehan,1998.2001,2003; Skehan\& Foster, 1999,2001) developed Limited Attentional Capacity Model. This model claims that task aspects and conditions of task performance can influence learners' attention to the accuracy, fluency or complexity of the language.

One way of sequencing tasks from simple to complex was developed by Brown et al (1984). He considered three types of tasks named as static, dynamic and abstract tasks. The first type is the easiest one in which all the information for carrying out the task is presented to the speaker. In the dynamic tasks, all the information is presented but the tasks can present problems in which the speaker has to describe the stimulus material be consistent in her/ his use of language. The last type, abstract tasks, is the most challenging one because the speaker is faced with abstract concepts and has to provide reasons for her/ his choice.

Rahimpour (2010) investigated the impact of task complexity on L2 learners' written narratives. In this study, the participants were asked to write narratives based on two different picture stories. He measured the accuracy, fluency and complexity by coding the written narratives. The result of this study proved that cognitively more demanding tasks were more fluent but the effect on fluency and accuracy was not significant.

Skehan's conception of task-based learning comes from a communicative approach to language teaching (Brumfit, 1984; Widdowson, 1972) which has been concerned, among other issues, with how task and syllabus design can contribute to interlanguage development. In Skehan's view (1998; Skehan\& Foster, 2001), both task manipulation and sequencing for syllabus design should be based not just on intuitions about difficulty but on empirical findings.

Having evidence of the effects of task demands on production can be used to direct learners' efforts toward different areas of performance separately or simultaneously. In addition to that, if links are established between production and acquisition, research evidence can be used to manipulate tasks to maximize the effectiveness of language learning.

Skehan (1998; Skehan\& Foster, 2001) suggests a three-way distinction of difficulty, to which learner factors can also be added:

Skehan's model of task difficulty, based on Skehan (1998).

\begin{tabular}{llll} 
Code complexity & Cognitive complexity & Communicative stress & Learner factors \\
\hline Linguistic complexity & Cognitive familiarity & Time pressure & Learner's intelligence \\
and variety & Familiarity of topic & Scale & Breadth of imagination \\
Vocabulary load and & Familiarity of discourse & Number of & Personal experience \\
variety & genre & participants & \\
& Familiarity of task & Length of text & \\
& Cognitive processing & used & \\
& Information organization & Modality & \\
& Amount of computation & Stakes & \\
& Clarity of information & Opportunity for & \\
& Sufficiency of information & control & \\
\hline
\end{tabular}

Skehan (1998) suggests that information should be collected with relation to the effects of task manipulation on the areas of fluency, accuracy, and complexity. He calls linguistic complexity to be a 'surrogate' of learners' willingness to stretch their interlanguage by experimenting with more difficult forms and by trying out more elaborate language. In his view, the information collected from the manipulation of task features can be used to establish longer-term pedagogic goals in which both meaning and form can be attended to, and in which interlanguage development can be integrated into fluent performance. Regarding sequencing, Skehan\& Foster (2001, p. 193-194) stipulate that:

"the individual task has to be located, in a principled way, in longer term instructional sequences which seek to promote balanced development, such that improvement in one area will be consolidated by improvements in others." 
Farahnaz Rimani Nikou \& Zarrin Eskandardoust (2012) also studied the effects of task complexity and task types on 60 EFL learners' written task performance regarding accuracy, complexity, and fluency. They operationalized complexity at two levels: simple and complex, and used two types of psycholinguistic tasks (decision- making and informationgap) in their study. The results of their study revealed that in decision- making tasks, task complexity had significant effect on accuracy and fluency of learners, but it did not have noticeable effect on syntactic complexity.

\section{Statement of the Problem}

Speaking English as an indispensible skill for EFL learners has always received much attention in second language research but despite the huge amount of research on this skill, it has been regarded as the most problematic and challenging area of second language acquisition among both the Iranian EFL teachers and learners.

Nowadays, not only do learners need to improve their speaking skill in educational setting but it seems quite necessary for them to use the language in real life situations.

Learning English as a foreign language is demanding task for the majority of Iranian learners and sometimes, is boring and tedious to them which require motivation and interest. Practicing speaking according to the right level of task complexity and sequence can make the students more motivated while practicing tasks in real- life situation. However one of the major problems in task- based syllabus design goes back to task sequence and complexity because the way in which different tasks are sequenced can have a great impact on learners' achievement in speaking ability.

\section{Research Question}

In line with the facts mentioned earlier in this paper, we tried to bridge the gap by conducting a study on the examining the effect of task complexity and sequence on speaking of EFL Iranian students and In order to get the good result, the present paper is an attempt to find the answer to the following question:

1. Is there any significant difference between the performances of L2 learners in term of fluency in doing complex tasks?

\subsection{Research Hypothesis}

Based on the formulated research question, the following null hypothesis was suggested:

Task sequence and complexity do not affect speaking ability of intermediate EFL learners.

\section{Purpose of the Study}

The primary objective of the study is to examine the effect of task complexity and sequence on EFL learners' speaking ability. Due to its importance in language teaching, speaking is viewed as the most important skill in task- based research and is worth enough for further empirical research. The ultimate goals of this study is to investigate the impact of task sequence and complexity in terms of accuracy, fluency, and complexity on speaking ability and thus pave the way of task- based instructors and syllabus designers in grading and sequencing tasks in a way that it can facilitate learning and teaching concurrently. The results of this study can help language learners be more motivated in conducting speaking tasks according to the right levels of complexity and also can be of help for syllabus designers to design the tasks in a way that will prepare learners for real life communication tasks.

\section{Methodology}

\subsection{Participants}

The participants were selected from among94 female students from Kish Language Institute in Rasht based on their performance on OPT test which was run to select 60 intermediate EFL learners. Then, they were divided randomly into two groups (control and experimental) each consisting of 30 participants.

\subsection{Instruments}

In this study, some picture stories with different levels of cognitive complexity, interview and Mp3 recorder were used to record the participants' voice and their complexity level was analyzed through two well- known models of task complexity, a map task adapted from Robinson (2001a) and a car task adapted from Lee (2002) with specific instructions for each task type (the reliability of the speaking test was estimated by test- retest method through directing the speaking test to the pilot study group twice and the correlation between these two sets of scores obtained from the two administrations was calculated), and the SPSS program was also used to analyze the data.

\subsection{Design and Procedures}

This study followed a quasi experimental design in which experimentation, library research and field work was used to gather the information of the study. The pretest was conducted to verify the level of the students in speaking and after that the experimental group received 10 sessions of the treatment. Materials undertaken in this investigation were a set of complex tasks chosen based on the criteria introduced by Robinson (2001) and Skehan\& Foster appropriate to the proficiency levels of the learners. Participants of the study were asked to view two picture stories with some helpful hints on them about a minute and then retell the story in their own words. The recorded data were transcribed and analyzed. To measure fluency and accuracy of the learners' oral production, T-test was employed to test the hypothesis.

\section{Data Analysis and Results}

To the extent that the research question is examined, an independent sample T-test was run to the results of the speaking post- test. It was run to compare the experimental and control groups in terms of their speaking ability after introducing 
the specific treatment to the experimental group and placebo for the control group. This time the results revealed that Task sequence and complexity affected speaking proficiency of the two groups differently $(\mathrm{t}=3.41,0.001<.05)$. In fact, learners' performance in the experimental group (Mean $=15.63)$ far outweighed that of the control group $($ Mean $=13.90)$ in posttest of speaking test.

Table 1. Group Statistics for the Control and Experimental Groups’ Post-Test Speaking Scores

\begin{tabular}{llllll}
\hline \multicolumn{2}{l}{ Group Statistics } & & & & \\
\multirow{2}{*}{ posttest } & groups & $\mathrm{N}$ & Mean & Std. Deviation & Std. Error Mean \\
& control & 30 & 13.9000 & 1.84484 & .33682 \\
\cline { 2 - 6 } & experimental & 30 & 15.6333 & 2.07586 & .37900 \\
\hline
\end{tabular}

Table 1 depicted the values of means and standard deviation along with standard error of mean for the two groups on posttest of speaking. The mean score of the experimental group (mean experimental group $=15.63$ ) is 1.73 points greater than that of the control group (mean control group $^{13.90)}$ ).

Table 2. Independent Samples Test for the Control and Experimental Groups' Post-Test Speaking Scores

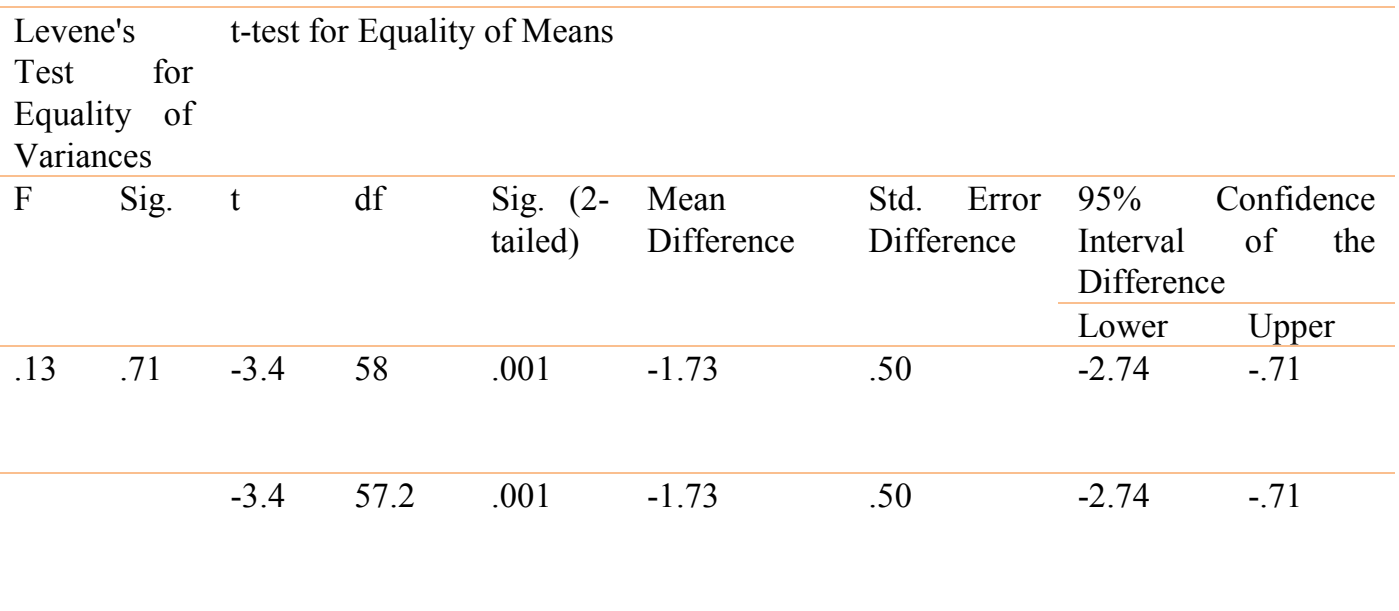

The independent sample T-test procedure offered two tests of the contrast between the control and experimental groups. The assumption for the first row was that the variances of the two groups were similar. The Levene statistic examined the fairness of the variances. The significance index of the statistic was .71. Since this rating was greater than.05, it could be assumed that the groups had equal variances and thus the second test was overlooked and the findings of the first test (first row) were documented.

The results of independent samples t-test for the post-test in tables 1, and 2 reflected that there was a significant difference between the two groups in their post- test $(\mathrm{p}<0.05)$. According to the findings, the experimental group markedly performed better than the control group in the post-test of speaking. The results showed that task sequence and complexity were effective in enhancing EFL learners' speaking ability in the experimental group and thus the null hypothesis is rejected. In other words, task sequence and complexity significantly affected Iranian intermediate EFL learners' speaking ability. The following figure depicts the two groups in speaking post-test at the end of the study.

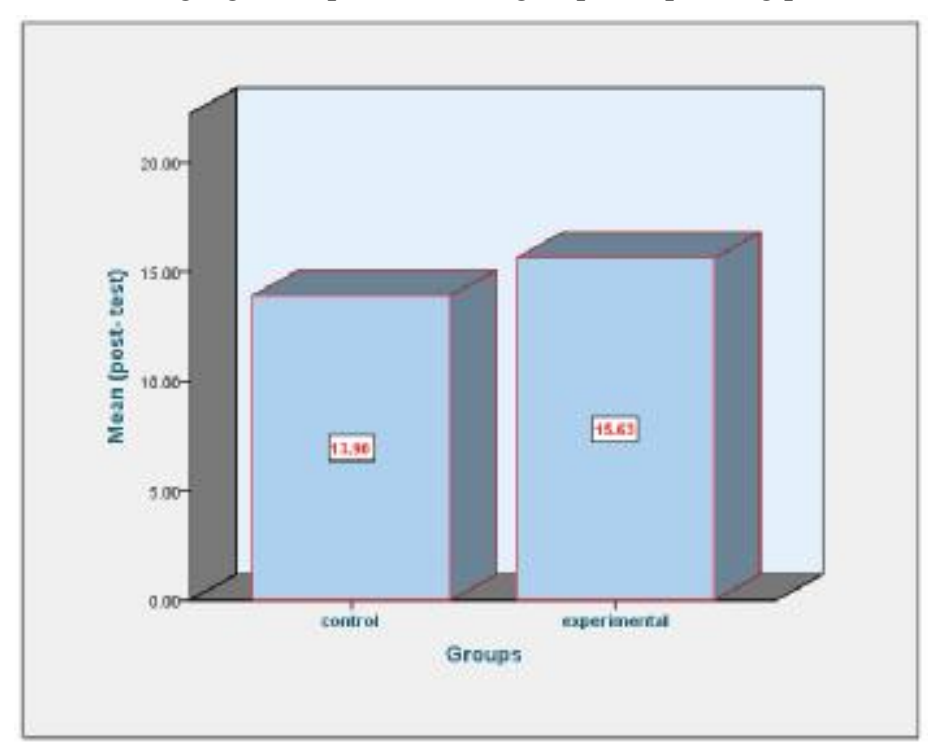

Figure1. The Comparison Between the Two Groups on Speaking Post- Test at The End of The Study 
In order to examine the effects of task sequence and complexity in enhancing EFL learners' speaking ability in three different areas including accuracy, fluency and complexity, descriptive statistics as well as independent samples T-tests were run to the results of each sections of the speaking test for both control and experimental groups in posttest. The findings are available in the following table:

Table 3. Group Statistics for the three sections of the speaking test (posttest)

\begin{tabular}{llllll} 
& groups & $\mathrm{N}$ & Mean & Std. Deviation & Std. Error Mean \\
\hline complexity & control & 30 & 5.2000 & .40684 & .07428 \\
\cline { 2 - 6 } fluency & experimental & 30 & 5.6667 & .47946 & .08754 \\
\hline accuracy & control & 30 & 4.9667 & .99943 & .18247 \\
& experimental & 30 & 5.6333 & 1.27261 & .23235 \\
\hline & control & 30 & 3.7333 & 1.01483 & .18528 \\
\hline
\end{tabular}

As it is reflected in Table 3, the experimental group outperformed the control group in all the three areas of the speaking test. Regarding the EFL learners' complexity of speaking, the mean of the experimental group amounted $(X=5.66)$, that of the control group came to $(\mathrm{X}=5.20)$.

When it comes to the participants' fluency of oral production, the mean of the experimental group exceeds than that of the control group $\left(X_{\text {experimental }}=5.63, X_{\text {control }}=4.96\right)$.

Additionally, the accuracy of the oral production for the participants in the experimental group $(\mathrm{X}=4.33)$ was higher than that of the control group $(\mathrm{X}=3.73)$.

Moreover, the mean of the complexity of the oral production $(X=5.66)$ was higher than other areas of the speaking test for the experimental group closely following by fluency $(X=5.63$ ?). The accuracy element received the lowest $\operatorname{mean}(\mathrm{X}=4.33)$.

In terms of the deviation of the scores, the degree of scatteredness of the scores for the experimental group in complexity and fluency was higher than that of the control group. Despite that, the variation of scores for the accuracy section of the oral production for the control group exceeded than that of the experimental group (see Table 3).

Table 4. Independent Samples Test for the Control and Experimental Groups' Post-Test Speaking Scores in three areas (accuracy, fluency and complexity)

\section{Levene's Test t-test for Equality of Means \\ for Equality \\ of Variances}

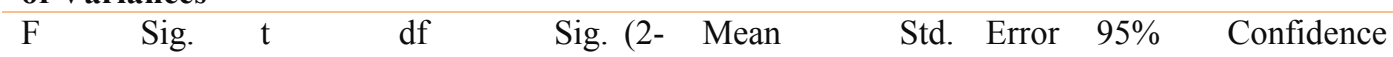

tailed) Difference Difference Interval of the

Difference

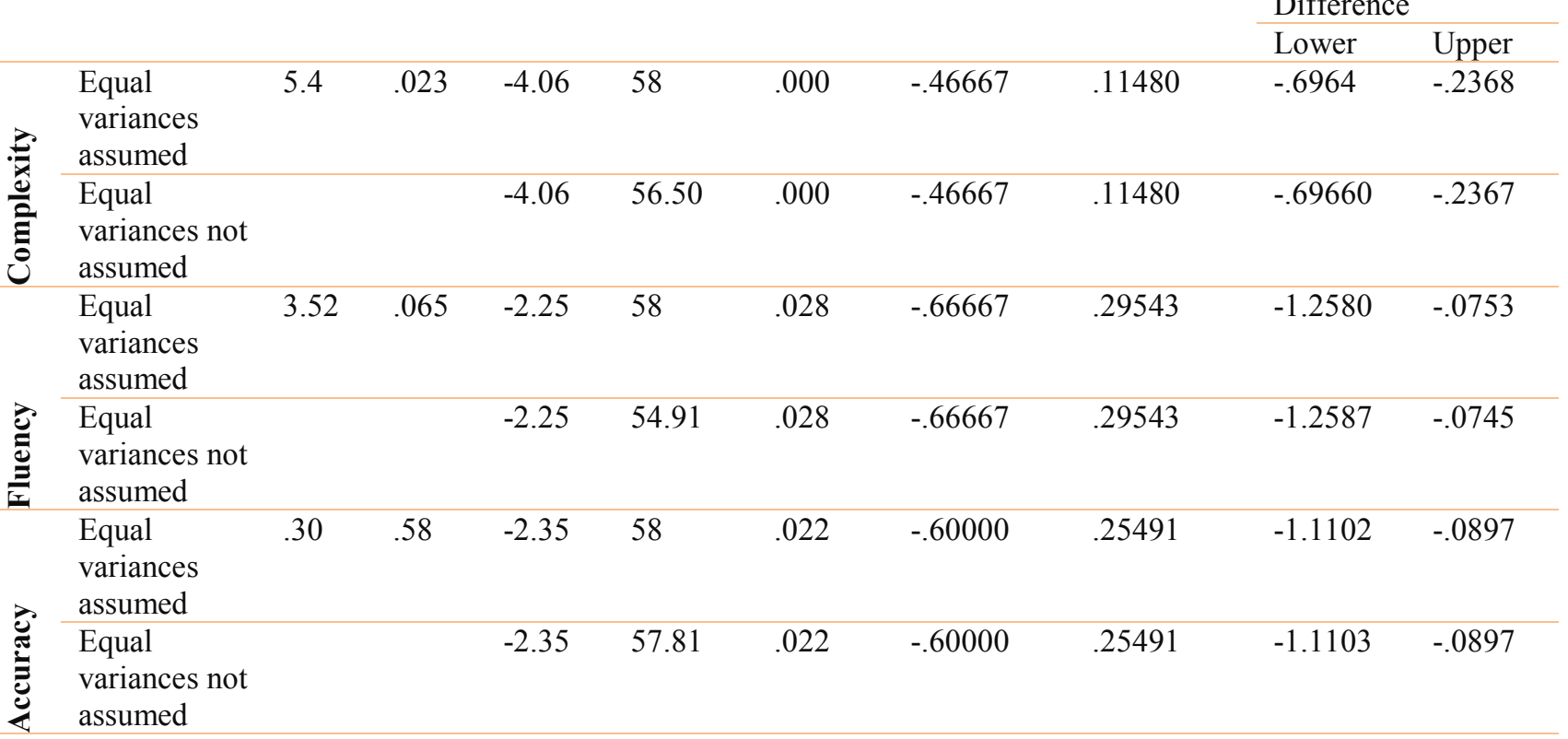

The findings of independent samples t-test for the post-test in tables 3 , and 4 reflected that there was also significant differences between the two groups in terms of their performance on three different areas of the speaking post- test $(p<0.05)$. According to the findings, the experimental group significantly outperformed the control group in all the three sections of the speaking test at the end of the study. The results showed that task sequence and complexity were effective in enhancing EFL learners' complexity, fluency and accuracy of the speaking ability in the experimental group .however, the most significant difference was found in complexity of the oral production between the two groups( sig= .000 ). The differences between the two groups in fluency and accuracy were also statistically significant (sig fluency $=$ .028 , sig accuracy $=.022$ ). The following figure depicts the two groups in sub sections of the speaking post-test at the end of the study. 


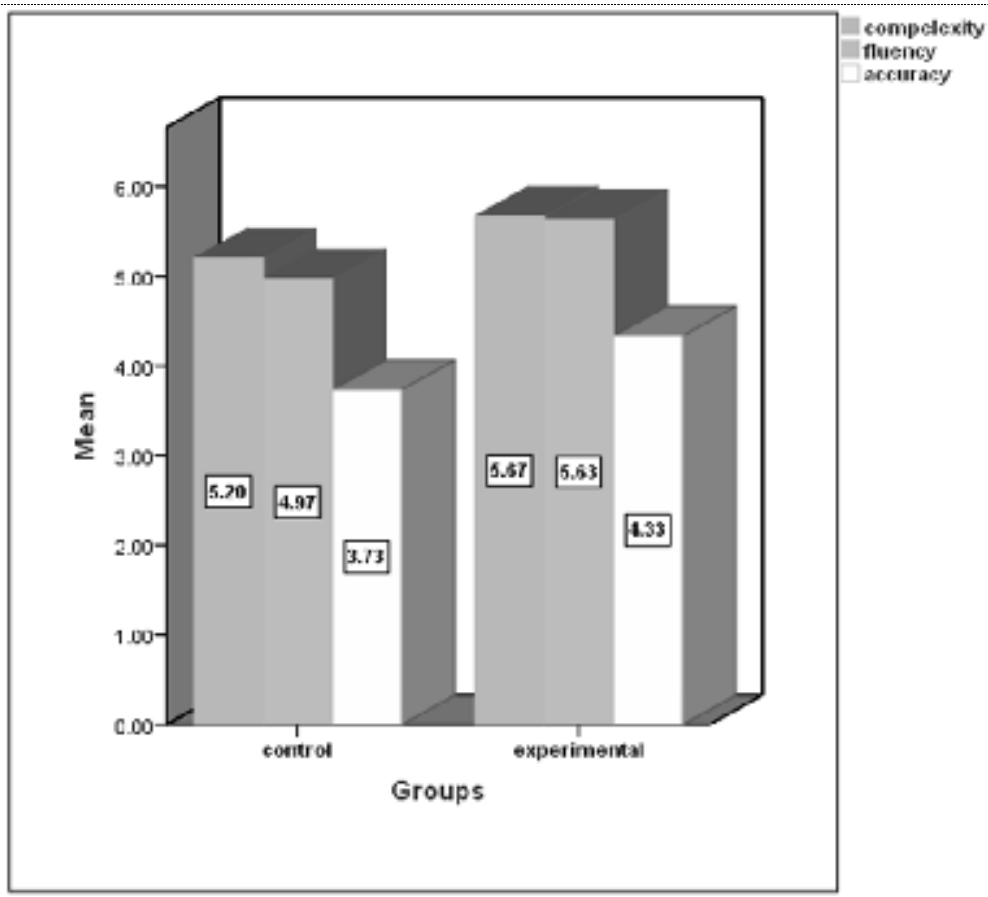

Figure 2. The Comparison between the Two Groups on Speaking Post- Test at the End of the Study

After determining the significant difference between the control and experimental groups in terms of their speaking ability at the end of the study, to investigate students' progress within groups, two paired t-tests were also run, which showed the subjects' progress in pre-test and post-test that are shown in Tables 5, and 6.

Table 5. Paired Samples Statistics

\begin{tabular}{llllll}
\hline \multirow{2}{*}{ Pair 1 } & Mean & N & Std. Deviation & Std. Error Mean \\
\cline { 2 - 6 } & Pretestspeaking & 13.5000 & 30 & 1.77628 & .32430 \\
\hline Posttest(Control group) & 13.9000 & 30 & 1.84484 & .33682 \\
\hline Pair 2 & & & & & \\
& $\begin{array}{l}\text { Pretestspeaking } \\
\text { Posttest (experimental } \\
\text { group) }\end{array}$ & 13.7000 & 30 & 1.91455 & .34955 \\
\hline
\end{tabular}

The mean score of the experimental group for speaking test has improved from 13.70 in pre- test to 15.63 in posttest; that of the control group has changed from 13.50 in pre- test to 13.90 in post- test.

Table 6. Paired Samples Test

\begin{tabular}{|c|c|c|c|c|c|c|c|}
\hline \multirow[t]{2}{*}{ Mean } & \multirow[t]{2}{*}{ Std. Deviation } & \multirow[t]{2}{*}{$\begin{array}{l}\text { Std. } \\
\text { Error } \\
\text { Mean }\end{array}$} & $\begin{array}{l}95 \% \\
\text { Interval } \\
\text { Difference }\end{array}$ & $\begin{array}{l}\text { Confidence } \\
\text { of the }\end{array}$ & \multirow[t]{2}{*}{$\mathrm{t}$} & \multirow[t]{2}{*}{$\mathrm{df}$} & \multirow[t]{2}{*}{ Sig } \\
\hline & & & Lower & Upper & & & \\
\hline-.400 & .67466 & .1231 & -.651 & -.148 & -2.24 & 29 & .063 \\
\hline
\end{tabular}

:

\begin{tabular}{|c|c|c|c|c|c|c|c|c|c|}
\hline 글 & $\begin{array}{l}\text { Pretestspeaking - } \\
\text { posttest( } \\
\text { experimental } \\
\text { group) }\end{array}$ & -1.933 & 1.4840 & .2709 & -2.487 & -1.379 & -7.13 & 29 & .000 \\
\hline
\end{tabular}

As it is depicted in the above tables, the difference between the pretest scores and posttest score of the experimental group was statistically significant $(\mathrm{p} \leq .05)$. On the other hand, the slight difference between the participants' scores in pre and posttest of speaking for the control group was not significant ( $\mathrm{p} \geq .05)$. 


\section{Discussion}

Several well- established studies have been conducted on the issues of TBLT (Foster \& Skehan, 1994; Mehrang \& Rahimpour,2010 ;Robinson, 2001b; Robinson (1996) on production of language learners. Skehan and Foster (Skehan,1998.2001,2003; Skehan\& Foster, 1999,2001) developed Limited Attentional Capacity Model which claims that task aspects and conditions of task performance can influence learners' attention to the accuracy, fluency or complexity of the language. Robinson (1996) found that a complex task resulted in more accurate production than a simple task; no significant results, however; were found regarding complexity measures. The study conducted by Farahnaz Rimani Nikou \& Zarrin Eskandardoust (2012) on the effects of task complexity and task types on 60 EFL learners' written task performance showed that in decision- making tasks, task complexity had significant effect on accuracy and fluency of learners, while it did not have significant effect on syntactic complexity.

This study was done to continue the previously conducted research by examining the effects of task complexity and sequence on speaking of EFL learners regarding all three areas of accuracy, fluency, and complexity. This research does suggest that task complexity and sequence do effect EFL learners' speaking ability mostly in production of more complex and fluent language.

\section{Conclusion}

An essential question and hypothesis were proposed and formulated. The hypothesis which claimed that task sequence and complexity did not have any effect on speaking ability of intermediate EFL learners was rejected and the result of the study proved that task sequence and complexity had significant effects on Iranian intermediate EFL learners' speaking ability in areas of fluency and complexity. In fact, learners' performance in the experimental group was much better than that of the control group in posttest of speaking test. The study also revealed that the participants in the experimental group, who practiced task sequence and complexity, had better performance in complexity than the two other areas of the speaking test. Their implementation on the accuracy section of the oral production was slightly lower than their performance in complexity and fluency sections.

At the end of the study, it was quite clear that task- based teaching had created a natural learning environment for learning in which students were much more motivated toward learning. Communicative fluency compatible with accuracy was also tangible during the treatment phase.

The results of the present study can provide both the experienced and newly- started teachers with provocative and wealth of implications. The experienced teachers can be more creative in choosing the pedagogic tasks with the right level of complexity and sequencing them in a way that the students can feel the variety and sense of achievement within their language while they are practicing to be more fluent speakers and the newly- started teachers are more flexible with the input which they have to bring to their classes and practice different tasks with students from the very beginning in a class which is more learner- centered but also allows them for the choice of suitable tasks.

It also paves the way for fundamental changes in syllabus design which is of high importance in language teaching and research. Syllabus designers can be much more innovative in the way they collect and design language textbooks according to TBLT and cater for all types of classrooms with different students and learning styles.

The most interesting point of departure for future research arising from the study could be to examine the effect of task complexity and sequence within different learning styles. The future studies can explore whether students with different learning styles would perform differently in oral production regarding task complexity and sequence.

\section{References}

Bachman, L. F. (2002). Some reflections on task-based language performance assessment. Language Testing, 19(4), 453-476.

Brown, G., Anderson, A., Shilcock, R. and Yule, G. (1984). Teaching talk: strategies for production and assessment. Cambridge: Cambridge University Press.

Bygate, M., Skehan, P., \& Swain, M. (2001). Introduction. In M. Bygate, P. Skehan \& M. Swain (Eds.), pedagogic tasks. Second language learning, teaching and testing. London: Longman.

Bygate, M., Skehan, P., \& Swain, M. (Eds.). (2001). Researching pedagogic tasks. Second language learning, teaching and testing. Harlow: Longman.

Ellis, R. (1994). The Study of Second Language Acquisition. Oxford Oxford University press.

Ellis, R. (2003). Task-based language learning and teaching. Oxford: Oxford University Press.

Ellis, R (Ed.) (2005). Planning and task performance in a second language. Amsterdam: John Benjamins.

Foster,P.andP. Skehan (1994). 'The influence of planning on performance in task-based learning' Paper presented at the British Association of Applied Linguistics, Leeds

Gilabert, R. (2005). Task complexity \& L2 narrative oral production. PhD thesis, University of Barcelona.

Kowal, M. and Swain, M. (1997). From semantic to syntactic processing: How can we promote it in the French immersion classroom? In Johnson, K. and Swain, M. (Eds.), Immersion Education: International Perspectives (pp. 284309). New York: Cambridge University Press. 
Long, M. H. \& Crookes, G. (1992). Three approaches to task-based syllabus design. TESOL Quarterly, $26(1), 27$.

Long, M. H. (1996). The role of linguistic environment in second language acquisition. In W.C.Ritchie\& T.K.Bhatia (Eds.). Handbook of second language acquisition. (pp.413-463). San Diego; Academic Press.

Mehrang, F. And Rahimpour, M. (2010). The impact of task structure and Planning conditions on oral performance of EFL learners. Procedia-Social and Behavioural Sciences.Vol.2, Issue 2, pp.3678-3686.

Nunan, D. (1993). Task-based syllabus design: Selecting, grading and sequencing tasks. In G. Crookes \& S. M. Gass (Eds.), Tasks in a pedagogical context. Clevedon, UK: Multilingual Matters.

Rahimpour M, Maghsoudpour M (2011). Teacher-students' interactions in task-based vs. form-focused instruction. World Journal of Education, 1(1),171-178.

Rimani Nikou, F. and Z. Skandarsefat. (2012). The Simultaneous Effects of Task Complexity and Task Types on EFL Learners' Written Performance. Australian Journal of Basic and Applied Sciences, 6(7): 137- 143.

Robinson, P. (1996). Connecting tasks, cognition and syllabus design. In P. Robinson (Ed.), Task complexity and second language syllabus design: Data- based studies and speculations (pp. 1-16). Brisbane: University of Queensland Working Papers in Applied Linguistics (Special Issue).

Robinson, P. (2001a). Task complexity, task difficulty and task production: Exploring Interactions in a componential framework. Applied Linguistics, 21, 27-57

Robinson, P. (2001b). Task complexity, cognitive resources, and syllabus design. In Robinson, P. (Ed.), Cognition and Second Language Instruction (pp. 287-318). Cambridge: Cambridge University Press.

Robinson, P., T. Cadierno, and Y. Shirai. (2009). Time and motion: Measuring the effects of the conceptual demands of tasks on second language speech production. Applied Linguistics 30, 533-544.

Skehan, P. (1996). A framework for the implementation of task-based instruction. Applied Linguistics 17(1) , 38-62.

Skehan, P. (1998). A Cognitive Approach to Language Learning. Oxford University Press.

Skehan, P. (2001). Tasks and language performance assessment. In M. Bygate, P.Skehan, and M. Swain (eds.) Researching pedagogic tasks, second language learning, teaching and testing. Harlow: Longman.

Skehan, P. and P. Foster. (1997). Task type and task processing conditions as influences on foreign language performance. Language Teaching Research 1, 185-211.

Skehan, P. and P. Foster (2010). The influence of planning and post-task activities on accuracy and complexity in task based learning. Thames Valley University

Skehan P. (2011d), (with S. Shen), .Task structure and task complexity in narrative retellings., In Skehan (2011a)

Skehan P. and P. Foster. (1999). The influence of task structure and processing conditions on narrative retellings. Language Learning 49(1), pp. 93-120.

Willis, D. \& Willis, J. (2001). Task-based language learning. In D, Nunan. \& Carter, R. (Eds.), The cambridge guide to teaching English to the speakers of the other languages (pp.173-179). Cambridge: Cambridge University Press. 